\title{
ANTIOXIDANT ENZYMES ACTIVITY IN EXPERIMENTAL ISCHEMIA-REPERFUSION INJURY
}

\section{N.V. Volotovska*, T.V. Kashchak \\ I. HORBACHEVSKY TERNOPIL NATIONAL MEDICAL UNIVERSITY, TERNOPIL, UKRAINE}

\begin{abstract}
Background. Blood loss during civil and military limb trauma is the most common cause of preventable death. Complications due to the use of a hemostatic tourniquet are widely investigated nowadays. Therefore, the standards of the past have to be improved.

Objective. The aim of the research is to study the reaction of the enzyme chain of the liver antioxidant system in the presence of modifications of ischemia-reperfusion injury (IRI).

Methods. 210 white male-rats, aged 5-5.5 months, were used in the research. The dynamics of antioxidant enzymes activity catalase (Cat) and superoxide dismutase (SOD) in liver tissue in cases of modifications of ischemiareperfusion injury (IRI) were studied. The period of investigation was in 24 hours, 3, 7, 14 days after the injury.

Results. In cases of simulated IRI the catalase level mainly decreased at each period of the experiment. The peak of SOD activity was evidenced on the $1^{\text {st }}, 3^{\text {rd }}$ or $7^{\text {th }}$ days after the experimental IRI according to the degree of trauma severity. Thus, IRI combined with severe blood loss and mechanical trauma caused the severest affection of the antioxidant system. Even a single application of hemostatic tourniquet caused similar wavelike reactions at different times.

Conclusions. The development of IRI is accompanied by a significant depression of the liver antioxidant system. The most significant changes were evidenced in cases of IRI combined with blood loss and mechanical trauma, but even a single application of a tourniquet caused active response of the antioxidant enzymes.

KEY WORDS: ischemia-reperfusion injury; trauma; blood loss; hemostatic tourniquet; catalase; superoxide dismutase.
\end{abstract}

\section{Introduction}

The damage to both skeletal muscles and internal organs caused by local ischemiareperfusion injury (IRI) is mostly present as a result of intraoperative use of tourniquet for temporary stop of blood circulation in internal organs or for stop of blood loss from the limb [1-10]. Primary damage leads to mechanical pressure, as for secondary mechanisms reactive oxygen intermediates and lipid peroxidation are responsible for it [11]. Nowadays, in state of affairs of Ukrainian hostilities, gunshot wounds are widespread, and use of hemostatic tourniquet is one of efficient methods. But complications accompanying it are more serious than it was though previously.

In the case of the hemostatic tourniquet use it is important to know about period of depression of antioxidant system in vitally important internal organs, for preventing exhaustion in further period consequences.

*Corresponding author: Nataliya V. Volotovska, MD, Ph.D., Department of Physiology, Bioethics and Biosafety, I.Horbachevsky Ternopil National Medical University, 1 Maidan Voli, Ternopil, Ukraine, 46001

E-mail: volotovskanv@tdmu.edu.ua
Oxidative stress is crucial in development of local and systemic damage and progress of ischemia-reperfusion injury in cases of oxygen insufficiency of the tissues [12]. Overproduction of reactive oxygen species (ROS) is combined with the violation of oxidative-reduction systems activity, damage of DNA, membrane receptors, dysfunction of ion channels and changes in composition of membrane phospholipids, as well as activation of caspase mechanism of apoptosis $[13,14,15]$. All this is leading to activation of endogenous antioxidant defense $[13,16-22]$.

Cellular systems of antioxidant protection are classified as enzymatic and non-enzymatic. The first one includes superoxide dismutase (SOD), glutathione peroxidase (GP), and catalase (Cat), which provide the first line of defense against the action of ROS in that way, when the product of the first reaction becomes a substrate for the next one [23].

Overexpression of SOD1 prevents neuronal death in the area of hippocampus [24]. However, the extremely short period of half-life of SOD1 in circulating blood makes it difficult to use enzyme therapy for brain damage. In 
some studies GP provides even greater defense against oxidative stress than SOD - its expression, as well as SOD provides cytoprotective effect $[16,18]$. Cat is a very important element in maintaining the intracellular concentration of reduced glutathione and is crucial in neutralization of free radicals $[24,25]$.

Various methods are used nowadays in therapeutic treatment: from lowering the temperature of the limb to the use of various drugs. Thus, the protective effect of curcumin on the myocardium, kidneys, nervous tissue and lung has been proved in cases of this pathology [26-29]; montelucast reduces the level of local and systemic manifestations [29], legalon, thiotriazolin, emoxipine, silymarin have antioxidant effect [3-9, 25-30]. Studying of changes in the activity of antioxidant enzymes is needed for prediction of the effect of a specific antioxidant corrector. This is essential to avoid exhaustion of the impaired body systems.

Objective. The aim of the research was to study the reaction of enzyme chain of the liver antioxidant system in the presence of modifications of IRI.

\section{Methods}

The experiments were performed on 210 non-linear white male rats, $250-270 \mathrm{~g}$ in weight and 5-5.5 months of age. They were divided into 5 groups, each of them contained 10 animals: the control group involved rats, which were administered thiopental-sodium anesthesia (40 mg/kg of body weight intramuscularly) only, the $1^{\text {st }}$ experimental group (tourniquet was applied to the upper thigh $1 / 3$ for 2 hours, reperfusion for 1 hour; the $2^{\text {nd }}$ experimental group (blood loos in amount of $40 \%$ of circulating blood volume was simulated; the $3^{\text {rd }}$ experimental group (a tourniquet on a thigh was combined with $40 \%$ blood loss from femoral vein of another lower limb), the $4^{\text {th }}$ experimental group (a tourniquet on a thigh was combined with femoral bone fracture of another lower limb), the $5^{\text {th }}$ experimental group (a tourniquet on a thigh was combined with $40 \%$ blood loss and femoral bone fracture of another lower limb).

The experiments were performed in the vivarium of $\mathrm{I}$. Horbachevsky TNMU in the morning. Special room had stable temperature $\left(18-22^{\circ} \mathrm{C}\right)$, relative humidity $(40-60 \%)$ and illumination 250 lux. Animals were sacrificed on the $1^{\text {st }}, 3^{\text {rd }}, 7^{\text {th }}$ and $14^{\text {th }}$ days after the trauma by thiopental-sodium anesthesia $(40 \mathrm{mg} / \mathrm{kg}$ of body weight intraperitoneally by total bloodletting from the heart. An activity of catalase (mckat/kg) and superoxide dismutase (U/mg) of $10 \%$ liver homogenate samples were determined by means of Koroliuk MA, et al. (1988) and Chevari S, et al. (1985) methods respectively.

All experimental stages of the research were performed following the European Convention for the Protection of Vertebrate Animals Used for Experimental and Other Scientific Purposes (Strasbourg, 1986), resolution of the First National Congress on Bioethics (Kyiv, 2001) and the Order of the Ministry of Health of Ukraine No. 690, dated September 23, 2009.

A statistical analysis of the attained data was performed by Excel (Microsoft, USA). Statistically significant differences between the independent indices were estimated by the Student t-test at normal distribution and by nonparametric methods in other cases. The results were presented as $(M \pm m)$, where $M$ means value, $\mathrm{m}$ - standard error. Correlation analysis was performed for the attained data. Linear correlation coefficient $(r)$ and its significance (b) were evaluated as well. The link was considered to be lost if the $r$ index was 0 , the link evidenced of a week correlation when the range was $0-0.03$. In the case of the range 0.3-0.7 - a medium link was established, the range of $0.7-1.0$ proved a strong interaction correlation. The correlation coefficient was significant at $p<0.05$.

\section{Results}

The total content of the investigated enzymes of the liver antioxidant system is presented in Table 1.

On the $1^{\text {st }}$ day, compare to the control, an increase of SOD in 3.1 times ( $1<0.01)$, by $80 \%$ (p2<0.01), by 13\% (p3<0.002), in 70\% (p4<0.003), in 4.6 times $(p 5<0.006)$ was evidenced. As for Cat, its level decreased the most. Thus, on the $1^{\text {st }}$ day its decrease in 24.1 times ( $\left.1<0.01\right)$, in 13.5 times ( $p 2<0.01)$, in 17.8 times $(p 5<0.004)$ took place as well as an increase by $16 \%$ (p3<0.004) and 38.6\% (p4<0.002).

On the $3^{\text {rd }}$ day, compare to the control, in all experimental groups there was an total increase of SOD activity in 3 times ( $1<0.003)$, in 5.4 times ( $2<0.007)$, in 3.6 times ( $3<<0.03)$, in 2.48 times $(p 4<0.01)$, by $86 \%(p 5<0.007)$. As for Cat, its dynamic was variable. A decrease in its level in 24 times $(\mathrm{p} 1<0.003)$, in 11.9 times ( $p 2<0.005)$ was evidenced, but in cases of other traumas - an increase of its level in 1.8 times 
$(p 3<0.3)$, by $77.6 \%(p 4<0.05)$, in 1.8 times (p5<0.08).

On the $7^{\text {th }}$ day, compare to the control, there was an evident increase if SOD activity in all experimental groups: in 13 times $(p 1<0.02)$, in 3.1 times $(p 2<0.006)$, in 12.8 times $(p 3<0.02)$, in 4.2 times $(p 4<0.009)$, in 5.3 times $(p 5<0.003)$. In all groups, except for the $3^{\text {rd }}$ one, a decrease of catalase activity was evidenced: in 3.5 times $(p 1<0.02)$, in 8.3 times $(p 2<0.005)$, in 15.2 times (p4<0.005), in $21.8 \%(\mathrm{p} 5<0.02)$. So, in the $3^{\text {rd }}$ group an increase in 12.8 times $(\mathrm{p} 3<0.02)$ took place.

The similar dynamic of SOD, compare to the control, was evidenced on the $14^{\text {th }}$ day. An increase in its level in 2.2 times ( $p 1<0.01)$, in 2.4 times ( $2<0.004)$, in 5.8 times $(p<0.006)$, in 2.36 times $(p 4<0.007)$, in 5.4 times $(p 5<0.01)$ took place.

As for Cat mostly depression was evidenced: a decrease of activity, compare to the control, in 10.3 times $(\mathrm{p} 2<0.005)$, in 13.2 times $(\mathrm{p} 3<0.004)$, in 1.67 times ( $p 4<0.05)$, in $21.4 \%$ ( $p 5<0.04)$, and a very slight increase of it in cases of isolated tourniquet - by $17 \%(\mathrm{p} 1<0.05)$.

In cases of activation of lipid peroxidation and oxidative stress, according to the literature, different levels of activity of the antioxidant system in all organs of the affected organism take place. The attained results proved that in 1 day in liver homogenate, the SOD activity increased in all experimental groups, but the most- in cases of a tourniquet alone and IRI combined with blood loss and mechanical trauma, when its level, compare to the control, increased in 3.1 and 4.6 times respectively.

In all groups, a wavelike reaction of enzyme activity was revealed. Thus, in cases of isolated IRI on the $1^{\text {st }}$ and $3^{\text {rd }}$ days it increased in 3-3.1 times; it suddenly increased (including the steady rates, compared with the previous periods) in 13 times, compare to the control, on the $7^{\text {th }}$ day - in 13 times; it did not reached the norm on the $14^{\text {th }}$ day. Blood loss only, associated with primarily hypoxia of the ischemic genesis, triggered activation with peak of its activity on the $3^{\text {rd }}$ day; it was still high. The combination of classic IRI with blood loss contained elements of both abovementioned manifestations: a mild increase in the activity (apparently due to the fight against hypoxia) in the presence of blood loss only as well as in cases of IRI only; the peak of increased SOD activity on the $7^{\text {th }}$ day reached 12.8-fold rate compare to the control.

The activity of SOD in cases of IRI combined with mechanical trauma increased and decreased very smoothly with its peak on the $7^{\text {th }}$ day, then it did not reached a normal level on the $14^{\text {th }}$ day, being higher than the initial level in 2.36 times, and lower than the previous period index by $44 \%$.

In cases of IRI combined with blood loss and mechanical trauma, two peaks of the SOD activity increase were evidenced: on the $1^{\text {st }}$ day (in 4.6 times, compare to the control) and in 5.3 times on the $7^{\text {th }}$ day, compare to the control. On the $3^{\text {rd }}$ day, which was obviously lifethreatening for this type of injury, the index

Table 1. Changes in superoxide dismutase $(\mathrm{U} / \mathrm{mg})$ and catalase activity (mckat/kg) in $10 \%$ liver homogenates of the studied rats in cases of modifications of ischemic reperfusion injury and isolated blood loss, $(\mathrm{M} \pm \mathrm{m})$.

\begin{tabular}{|c|c|c|c|c|c|c|c|}
\hline \multicolumn{2}{|c|}{ Group } & \multirow[b]{2}{*}{ Indices } & 1 & 2 & 3 & 4 & 5 \\
\hline $\begin{array}{c}\text { Post } \\
\text { traumatic } \\
\text { period }\end{array}$ & Control & & $\begin{array}{c}\text { Tourniquet } \\
T\end{array}$ & $\begin{array}{c}\text { Blood loss } \\
\text { BL }\end{array}$ & $\mathrm{T}+\mathrm{BL}$ & $\mathrm{T}+\mathrm{F}$ & $\mathrm{T}+\mathrm{BL}+\mathrm{F}$ \\
\hline \multirow{2}{*}{$\begin{array}{l}\text { In } 24 \\
\text { hours } \\
\text { after } \\
\text { trauma }\end{array}$} & \multirow[t]{4}{*}{$\begin{array}{c}\text { SOD } \\
0.15 \pm 0.09\end{array}$} & SOD & $0.47 \pm 0.06$ * & $0.27 \pm 0.04 *$ & $0.17 \pm 0.01$ & $0.26 \pm 0.02 *$ & $0.70 \pm 0.02 *$ \\
\hline & & Cat & $0.18 \pm 0.08 *$ & $0.33 \pm 0.07 *$ & $5.17 \pm 0.02 *$ & $6.15 \pm 0.01 *$ & $0.25 \pm 0.02 *$ \\
\hline \multirow{2}{*}{$\begin{array}{l}\text { In } 3 \text { days } \\
\text { after } \\
\text { trauma }\end{array}$} & & SOD & $0.45 \pm 0.02$ & $0.82 \pm 0.03 *, * *$ & $0.54 \pm 0.16 *, * *$ & $0.37 \pm 0.01 *, * \star$ & $0.28 \pm 0.03 *, \star *$ \\
\hline & & Cat & $0.18 \pm 0.01 *$ & $0.37 \pm 0.02 *$ & $8.01 \pm 1.3^{*, \star *}$ & $7.89 \pm 0.3 *, \star \star$ & $8.09 \pm 0.36 *, * *$ \\
\hline \multirow{2}{*}{$\begin{array}{l}\text { In } 7 \text { days } \\
\text { after } \\
\text { trauma }\end{array}$} & \multirow{4}{*}{$\begin{array}{c}\text { Cat } \\
4.44 \pm 0.36\end{array}$} & SOD & $1.94 \pm 0.05 *, \star \star$ & $0.47 \pm 0.03 *, \star *$ & $1.93 \pm 0.06 *, \star *$ & $0.29 \pm 0.02 *, \star *$ & $0.80 \pm 0.02 *, \star *$ \\
\hline & & Cat & $1.28 \pm 0.16 *, \star \star$ & $0.54 \pm 0.02 *, * *$ & $6.63 \pm 0.27 *, * *$ & $0.63 \pm 0.04 *, * \star$ & $3.47 \pm 0.05^{*, \star *}$ \\
\hline \multirow{2}{*}{$\begin{array}{l}\text { In } 14 \text { days } \\
\text { after } \\
\text { trauma }\end{array}$} & & SOD & $0.32 \pm 0.06 *, * *$ & $0.36 \pm 0.03 *, \star *$ & $0.88 \pm 0.02 *, \star *$ & $0.35 \pm 0.03 *, \star *$ & $0.83 \pm 0.06$ * \\
\hline & & Cat & $5.20 \pm 0.36 *, \star \star$ & $0.43 \pm 0.03 *$ & $0.34 \pm 0.02 *, * *$ & $2.65 \pm 0.20 *, \star *$ & $3.49 \pm 0.20$ * \\
\hline
\end{tabular}

Notes: * - statistical significance compare to the control, ** - statistical significance compare to the previous period of the study. 
slightly exceeded the initial control level, but was statistically significantly lower than on the $1^{\text {st }}$ day (in 2.5 times). On the $14^{\text {th }}$ day it was still increased and the same as on the $7^{\text {th }}$ day.

In cases of IRI only, the dynamics of Cat activity was depressed with a peak of decrease on the $3^{\text {rd }}$ day (in 24 times). In the presence of blood loss only in all study periods, the activity of catalase was statistically significantly lower compare to the control.

The peculiar features of the IRI course combined with blood loss was an increase in the activity of this enzyme on the $3^{\text {rd }}$ day in 1.8 times compare to the control; on the $14^{\text {th }}$ day the index decreased in 13.2 times compare to the control, and in 23.6 times compare to that on the $3^{\text {rd }}$ day.

A somewhat similar dynamics of catalase activity was evidenced in cases of IRI combined with mechanical trauma, when after a gradual increase till the $3^{\text {rd }}$ day, it suddenly decreased in 15.2 times compare to the control on the $7^{\text {th }}$ day. Although, the index was still decreased on the $14^{\text {th }}$ day being lower than the initial level in 1.67 times.

The peculiar features of the Cat dynamics in cases of IRI combined with blood loss and mechanical trauma, was a sudden decrease of its activity on the $1^{\text {st }}$ day compare to the control; then the Cat activity suddenly increased on the $3^{\text {rd }}$ day in 1.8 times compare to the control and was of the initial level up to the end of the experimental period, which obviously proved the reduction of enzymatic component on the $14^{\text {th }}$ day.

\section{Discussion}

The correlative analysis proved that, in development of ischemia-reperfusion syndrome caused by application of hemostatic tourniquet, liver failure is significant. This is the focus of the further research on morphological changes of liver tissue. Hepatic active response is a predictable reaction, which belongs to the multiply organ failure syndrome. Association of IRI as the cause of such pathological effect in the organism was proved by a couple of researchers [32-36].

Probably, the depression of SOD is caused by overproduction of malonic dialdehyde and other derivates of peroxidation. Detection of reactive oxygen intermediates accumulation, enzymes of cytolysis and oxidative modification of proteins might be studied in our future experiments, as these indexes are typical in such course of pathological external affection $[37,38]$. Moreover, the data on changes in the activity of serum and organ catalase in cases of trauma and blood loss vary. Both decrease and increase of Cat level were presented in different experimental studies [13, 21, 22]. And in our research such fluctuations of this enzyme activity were proved.

In our case active response of the liver antioxidant system was evidenced by an increased activity of antioxidant enzymes. Our studies coincide with those of other researches. E. Orlova et al. proved that SOD activity was the highest in liver and they advised correction of its insufficiency with Vin-Vita [23]. Affection of liver tissue caused by application of tourniquet led to possible development of multiple organ failure due to the ischemic-reperfusion limb syndrome [37].

Besides, we consider that IRI combined with mechanical trauma may cause development of abrupt affecting of the liver antioxidant system that was proved by higher level of SOD activity than in other groups and which was still increased till the end of experiment. Such dynamics of SOD and Cat activity is a result of lipid peroxidation, i.e. increase in malonic dialdehyde level $[2,11]$. It has been established that reperfusion syndrome affects the development of systemic changes in cases of combined trauma complicated by bleeding that is manifested by a significant activation of lipid peroxidation.

\section{Conclusions}

Even a single use of a hemostatic tourniquet leads to significant changes in the activity of enzymatic level of antioxidant defense. In present hostilities, blood loss is often combined with skeletal injuries, so it is advisable to limit the time of use of a hemostatic tourniquet or to take measures that counteract the development of lipid peroxidation caused by an injury in the need of bleeding stopping with a tourniquet.

\section{Conflict of interest}

The authors declare no conflict of interest. 


\title{
ЗМІНА АКТИВНОСТІ ФЕРМЕНТІВ АНТИОКСИДНОГО ЗАХИСТУ ПРИ ЕКСПЕРИМЕНТАЛЬНОМУ ІШЕМІЧНО-РЕПЕРФУЗІЙНОМУ СИНДРОМІ
}

\author{
Н.В. Волотовська, Т.В. Кащак \\ ТЕРНОПІЛЬСЬКИЙ НАЦІОНАЛЬНИЙ МЕДИЧНИЙ УНІВЕРСИТЕТ IМЕНІ І.Я. ГОРБАЧЕВСЬКОГО, \\ ТЕРНОПІЛЬ, УКРАЇНА
}

Вступ. Крововтрата при цивільній та бойовій травмі кінцівок є найпоширенішою причиною т.з. «превентивних смертей». Оскільки стандарти минулого щодо надання невідкладної медичної допомоги для зупинки кровотеч потребують поліпшення, сьогодні широко досліджуються ускладнення при накладанні гемостатичного джгута.

Мета дослідження. Вивчити особливості реакції ферментативної ланки антиоксидантноі системи печінки на тлі модифікацій ішемічно-реперфузійного синдрому (IPC).

Методи дослідження. У експерименті використано 210 білих щурів-самців віком 5-5,5 місяців. Досліджено динаміку активності антиоксидантних ферментів каталази (Kam) та супероксиддисмутази (СОД) в тканині печінки при розвитку модифікацій IPC. Забір зразків тканини здійснювали через 24 години, на 3, 7 та 14 доби після травми.

Результати. У наших моделях IPC рівень Кат в основному зменшувався в кожному періоді експерименту. Пік активності СОД спостерігався на 1, 3 або 7 добу після експериментального IPC згідно модифікацій ступенів тяжкості травми. Таким чином, застосування кровоспинного джгута в поєднанні з втратою крові та механічною травмою, викликали найважчі ураження антиоксидної системи. При цьому, навіть одноразове застосування джгута викликало подібні хвилеподібні реакції.

Висновки. Розвиток IPC супроводжується сильним пригніченням антиоксидної системи печінки. Найбільш значні зміни спостерігалися на тлі застосування кровоспинного джгута, поєднаного з втратою крові та механічною травмою, але навіть ізольоване застосування джгута викликало суттєву зміну активності антиоксидних ферментів.

КЛЮЧОВІ СЛОВА: ішемічно-реперфузійний синдром; травма; втрата крові; гемостатичний джгут; каталаза; супероксиддисмутаза.

\section{Інформація про авторів}

Волотовська Наталія Володимирівна - канд. мед. наук, асистент кафедри фізіології з основами біоетики та біобезпеки, Тернопільський національний медичний університет імені І.Я. Горбачевського МОЗ України.

Кащак Тетяна Василівна - асистент кафедри фізіології з основами біоетики та біобезпеки, Тернопільський національний медичний університет імені І.я. Горбачевського МОЗ України.

\section{Information about authors}

Nataliya V. Volotovska - MD, Ph.D., Department of Physiology, Bioethics and Biosafety, I. Horbachevsky Ternopil National Medical University.

ORCID 0000-0003-4073-3148, e-mail: volotovskanv@tdmu.edu.ua

Tetiana V. Kashchak - assistant professor, Department of Physiology, Bioethics and Biosafety, I. Horbachevsky Ternopil National Medical University.

e-mail: kachaktv@tdmu.edu.ua

\section{References}

1. Khanna A, Cowled PA, Fitridge RA. Nitric oxide and skeletal muscle reperfusion injury: current controversies (research review). Journal of Surgical Research. 2005 Sep 1;128(1):98-107.

doi: 10.1016/j.jss.2005.04.020

2. Wang WZ, Baynosa RC, Zamboni WA. Update on ischemia-reperfusion injury for the plastic surgeon: 2011. Plastic and reconstructive surgery. 2011 Dec1;128(6):685e-92e.

doi: 10.1097/PRS.0b013e318230c57b
3. Van der Spuy L. Complications of the arterial tourniquet South Afr J Anaesth Analg. 2012;18(1):14-8. doi: 10.1080/22201173.2012.10872818

4. Dennis DA, Kittelson AJ, Yang CC, Miner TM, Kim RH, Stevens-Lapsley JE. Does Tourniquet Use in TKA Affect Recovery of Lower Extremity Strength and Function? A Randomized Trial. Clin Orthop Relat Res. 2016 Jan;474(1):69-77.

doi: $10.1007 / \mathrm{s} 11999-015-4393-8$. 
5. Cengiz M1, Ulker P, Meiselman HJ, Baskurt OK. Influence of tourniquet application on venous blood sampling for serum chemistry, hematological parameters, leukocyte activation and erythrocyte mechanical properties. Clin Chem Lab Med. 2009;47(6):769-76.

doi: 10.1515/CCLM.2009.157.

6. Tuncali B, Boya H, Kayhan Z, Arac S.Tourniquet pressure settings based on limb occlusion pressure determination or arterial occlusion pressure estimation in total knee arthroplasty? A prospective, randomized, double blind trial Acta Orthop Traumatol Turc. 2018 Jul;52(4):256-60.

doi: 10.1016/j.aott.2018.04.001.

7. Rao PR, Viswanath RK. Cardioprotective activity of silymarin in ischemia-reperfusion-induced myocardial infarction in albino rats. Exp Clin Cardiol. 2007;12(4):179-87.

8. Ligeret $H$, Brault $A$, Vallerand $D$, Haddad $Y_{\text {, }}$ Haddad PS. Antioxidant and mitochondrial protective effects of silibinin in cold preservation-warm reperfusion liver injury. J Ethnopharmacol. 2008; 115(3): 507-14.

doi: 10.1016/j.jep.2007.10.024

9. Senturk H, Kabay S, Bayramoglu G, Ozden H, Yaylak F, Yucel M, Olgun EG, Kutlu A. Silymarin attenuates the renal ischemia/reperfusion injuryinduced morphological changes in the rat kidney. World J Urol. 2008; 26(4): 401-7.

doi: $10.1007 / \mathrm{s} 00345-008-0256-1$

10. Hou YC, Liou KT, Chern CM, Wang YH, Liao JF, Chang $S$, et al. Preventive effect of silymarin in cerebral ischemia-reperfusion-induced brain injury in rats possibly through impairing NF-KB and STAT-1 activation. Phytomedicine. 2010 Oct;17(12):963-73.

doi: 10.1016/j.phymed.2010.03.012

11. Görgülü A, Kiriş T, Unal F, Turkoğlu U, Küçük M, Cobanoğlu S. Superoxide dismutase activity and the effects of NBQX and CPP on lipid peroxidation in experimental spinal cord injuryRes Exp Med (Berl). 2000; 199(5): 285-93.

doi: $10.1007 / \mathrm{s} 004330050126$

12. Ergün Yu, Üremis $M$, Kılınç $M, A l ı c ı ~ T$. Antioxidant effect of Legalon(r) SIL in ischemiareperfusion injury of rat skeletal muscle. Acta Cir. Bras. 2016; 31(4): 264-70.

doi: $10.1590 / S 0102-865020160040000007$

13. Işlekel S1, Işlekel H, Güner G, Ozdamar N. Alterations in superoxide dismutase, glutathione peroxidase and catalase activities in experimental cerebral ischemia-reperfusion. Res. Exp. Med.1999; 199: 67-76.

doi: $10.1007 / \mathrm{s} 004330050121$

14. Valko M1, Izakovic M, Mazur M, Rhodes CJ, Telser J. Role of oxygen radicals in DNA damage and cancer incidence. Mol Cell Biochem. 2004; 266(1-2): 37-56.

doi: 10.1023/B:MCBI.0000049134.69131.89

15. Hudyma AA, Kashchak TV, Shepitko KV. Antioxidant-prooxidant and cytokine balance in the late period of combined trauma in the experiment. World of Medicine and Biology. 2019;1(67):42-7. doi: 10.26724/2079-8334-2019-1-67-42
16. Kim GW, Lewén A, Copin J, Watson BD, Chan $\mathrm{PH}$. The cytosolic antioxidant, copper/zinc superoxide dismutase, attenuates blood-brain barrier disruption and oxidative cellular injury after photothrombotic cortical ischemia in mice. Neuroscience. 2001; 105(4):1007-18.

doi: 10.1016/S0306-4522(01)00237-8

17. Kleinschnitz C, Grund $H$, Wingler $K$, Armitage $M E$, Jones $E$, Mittal $M$, et al. Post-stroke inhibition of induced NADPH oxidase type 4 prevents oxidative stress and neurodegeneration. PLoS Biology. 2010;8:1-13.

doi: 10.1371/journal.pbio.1000479

18. Kofler J, Hurn PD., Traystman RJ. SOD1 overexpression and female sex exhibit regionspecific neuroprotection after global cerebral ischemia due to cardiac arrest. J. Cereb Blood. Flow. Metab. 2005; 25:11-30.

doi: 10.1038/sj.jcbfm.9600119

19. Rodrigo R, Fernández-Gajardo R, Gutiérrez R, Matamala JM, Carrasco R, Miranda-Merchak A, et al. Oxidative stress and pathophysiology of ischemic stroke: novel therapeutic opportunities. CNS Neurol Disord Drug Targets. 2013;12:698-714.

doi: $10.2174 / 1871527311312050015$

20. Valko M, Leibfritz D, Moncol J, Cronin MT, Mazur M, Telser J. Free radicals and antioxidants in normal physiological functions and human disease. Int.J Biochem. Cell. Biol. 2007;39:44-84.

doi: 10.1016/j.biocel.2006.07.001

21. Yan BC, Park JH, Ahn JH, Kim IH, Park OK, Lee JC, et. al. Neuroprotection of posttreatment with risperidone, an atypical antipsychotic drug, in rat and gerbil models of ischemic stroke and the maintenance of antioxidants in a gerbil model of ischemic stroke. J. Neurosci. Res. 2014;92:795-807.

doi: 10.1002/jnr.23360

22. Zhang YB, Kan MY, Yang ZH, Ding WL, Yi J, Chen HZ, Lu Y. Neuroprotective effects of N-stearoyltyrosine on transient global cerebral ischemia in gerbils. Brain Res. 2009; 1287: 146-56.

doi: 10.1016/j.brainres.2009.06.070

23. Orlova EA, Lazarchuk OA. Activity of cytosol superoxide dismutase in rats' tissues at parapharmaceutics «Vin-Vita». Ukrainian Journal of Clinical and Laboratory Medicine. 2010;5(3):87-90 [in Russian].

24. Steare SE., Yellon DM. The protective effect of heat stress against reperfusion arrhythmias in the rat. J. Mol. Cell. Cardiol. 1993;25:71-81.

doi: 10.1006/jmcc.1993.1163

25. Voronkov AV, Pozdnyakov DI, Ruri EI, Ribalko AE. Comparison of the antioxidant activity of mexidol in different origin brain damage in the experiment. Sovremennyie problemyi nauki i obrazovaniya. 2016;6 [in Russian]:

http://www.science-education.ru/ru/article/ view?id=25392.

26. Takhtfooladi HA, Takhtfooladi HA, Takhtfooladi MA. Effect of curcumine on lung injury induced by skeletal muscle ischemia/reperfusion in rats. Ulus Travma Acil Derg. 2019;25(1):7-11. doi: $10.5505 /$ tjtes.2018.83616 
27. Takhtfooladi MA, Takhtfooladi HA, Sedaghatfar H, Shabani S. Effect of low-level laser therapy on lung injury induced by hindlimb ischemia/ reperfusion in rats. Lasers Med Sei. 2015;30:1757-62. doi: 10.1007/s10103-015-1786-6

28. Calapai G, Squadrito F, Rizzo A, Marciano MC, Campo GM, Caputi AP. Multiple actions of the coumarine derivative cloricromene and its protective effects on ischemic brain injury. Naunyn Schmiedebergs Arch Pharmacol. 1995;351(2):209-15.

doi: 10.1007/BF00169335

29. Calapai G, Marciano MC, Corica F, Allegra A, Parisi A, Frisina N, et al. Erythropoietin protects against brain ischemic injury by inhibition of nitric oxide formation. Eur J Pharmacol. 2000;401(3): 349-56.

doi: 10.1016/S0014-2999(00)00466-0

30. Bilgiç Mİ, Altun G, Çakıcı H, Gideroğlu K, Saka G. The protective effect of Montelukast against skeletal muscle ischemia/reperfusion injury: An experimental rat model. Turkish Journal of Trauma and Emergency Surgery. 2018;24(3):185-190.

doi: 10.5505/tjtes.2017.22208

31. Demir M, Amanvermez R, Kamalı Polat A, Karabıçak I, Çınar H, Kesicioğlu T, and Polata C. The effect of silymarin on mesenteric ischemia-reperfusion injury. Med Princ Pract. 2014;23(2):140-4.

doi: 10.1159/000356860

32. Tsymbaliuk HY. Dynamics of antioxidantprooxidant system in kidney's tissue at abdominal trauma, hypovolemic shock and ischemia-reperfusion syndrome Hospital Surgery. Journal named by L.Ya. Kovalchuk. 2018;3:63-9. [in Ukrainian]. doi: $10.11603 / 2414-4533.2018 .3 .8898$
33. Aslan T, Turer MD, Joseph A, Hill MD. Pathogenesis of myocardial ischemia-reperfusion injury and rationale for therapy The American J of Card. 2010;106(3):360-368.

doi: 10.1016/j.amjcard.2010.03.032

34. Tarasiuk VS, Matviichuk MV, Palamar IV, Koroliova ND, Poliarush VV, Podolian VM, et al. The outlooks on the temporary bleeding control methods in the combat conditions. Reports of Vinnytsia National Medical University. 2017;1(21):220-7. [in Ukrainian].

35. Byrne RM, Taha AG, Avgerinos E, Marone LK, Makaroun MS, Chaer RA. Contemporary outcomes of endovascular interventions for acute limb ischemia. J Vasc Surg 2014;59(4):988-995.

doi: $10.1016 / j$.jvs.2013.10.054

36. Fukuda I, Chiyoya M, Taniguchi S, Fukuda W. Acute limb ischemia: contemporary approach. Gen Thorac Cardiovasc Surg. 2015; 63 (10): 540-548. doi: $10.1007 / \mathrm{s} 11748-015-0574-3$

37. Tsymbaliuk HY. Daily urine renal state under ischemic-reperfusion syndrome of limbs, abdominal injury with hypovolemic shock and their combination in the early period of traumatic disease. Achievements of Clinical and Experimental Medicine. 2018;3: 163-169.

doi: 10.11603/1811-2471.2018.v0.i3.9350

38. Salvadori M, Rosso G, Bertoni E. Update on ischemia-reperfusion injury in kidney transplantation: Pathogenesis and treatment. World J Transplant. 2015; 5:52-67.

doi: $10.5500 /$ wjt.v5.i2.52

Received 19 May 2019; revised 30 May 2019; erevised 03 June; accepted 18 June 2019.

This is an open-access article distributed under the terms of the Creative Commons Attribution License, which permits unrestricted use, distribution, and reproduction in any medium, provided the original author and source are credited. 